\title{
Cognitive capacity and functional development assessment in elderly people with Type 2 Diabetes Mellitus
}

Avaliação da capacidade cognitiva e do desenvolvimento funcional em adultos idosos com diabetes mellitus tipo 2

Evaluación de la capacidad cognitiva y del desarrollo funcional en adultos mayores con diabetes mellitus tipo 2

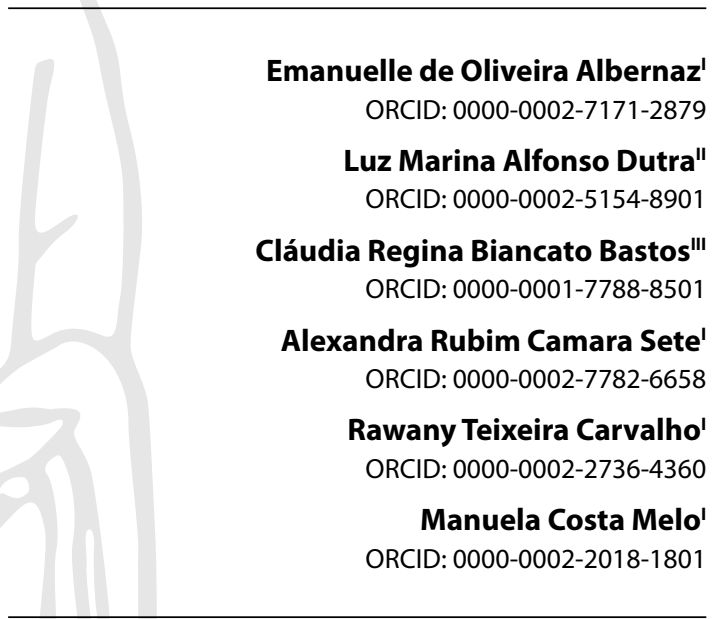

'Escola Superior de Ciências da Saúde. Brasília, Federal District, Brazil.

"Universidade de Brasília. Brasília, Federal District, Brazil. I' Universidade Norte do Paraná. Ponta Grossa, Paraná, Brazil.

How to cite this article: Albernaz EO, Dutra LMA, Bastos CRB, Sete ARC, Carvalho RT, Melo MC. Cognitive capacity and functional development assessment in elderly people with Type 2 Diabetes Mellitus. Rev Bras Enferm. 2021;74(5):e20190306. https://doi.org/10.1590/0034-7167-2019-0306

Corresponding Author: Emanuelle de Oliveira Albernaz Email:emanuelle.albernaz@hotmail.com

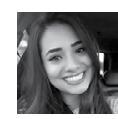

EDITOR IN CHIEF: Dulce Barbosa ASSOCIATE EDITOR: Maria Saraiva

\section{ABSTRACT}

Objective: to analyze the cognitive capacity and functional development of the elderly with and without diabetes. Methods: case-control study, comparing elderly people with and without diabetes. 218 patients interviewed in outpatient clinics: geriatrics and endocrinology. Validated instruments were used for cognitive and functional assessment. Results: people with diabetes had low scores on cognitive tests. $\mathrm{HbA} 1 \mathrm{c}$ and education were related to memory loss, compromising the basic and instrumental activities of daily life. Conclusion: this study evaluated that high glycemic values affect the autonomy of the elderly, compromising cognition and functional performance in activities of daily living.

Descriptors: Health of the Elderly; Cognition; Self-Care; Diabetes Mellitus; Secondary Care.

\section{RESUMO}

Objetivo: analisar a capacidade cognitiva e desenvolvimento funcional de pessoas idosas com e sem diabetes. Métodos: estudo de caso-controle, comparando idosos com e sem diabetes. 218 pacientes entrevistados em clínicas ambulatoriais: geriatria e endocrinologia. Instrumentos validados foram utilizados para avaliação cognitiva e funcional. Resultados: pessoas com diabetes tiveram pontuação baixa em testes cognitivos. HbA1c e educação tiveram relação com perda de memória, comprometendo as atividades básicas e instrumentais do cotidiano. Conclusão: Este estudo permitiu avaliar que altos valores glicêmicos afetam a autonomia dessas pessoas idosas, comprometendo a cognição e desempenho funcional nas atividades da vida diária. Descritores: Saúde do Idoso; Cognição; Autocuidado; Diabetes Mellitus; Atenção Secundária à Saúde.

\section{RESUMEN}

Objetivo: analizar la capacidad cognitiva y el desarrollo funcional de los ancianos con y $\sin$ diabetes. Métodos: estudio de casos y controles, comparando personas mayores con y sin diabetes. 218 pacientes entrevistados en consultas externas: geriatría y endocrinología. Instrumentos validados utilizados para la evaluación cognitiva y funcional. Resultados: personas con diabetes con puntuaciones bajas en pruebas cognitivas. La HbA1c y la educación se relacionaron con la pérdida de memoria, comprometiendo las actividades básicas e instrumentales de la vida diaria. Conclusión: evaluó que valores altos de glucemia afectan la autonomía de los ancianos, comprometiendo la cognición y el desempeño funcional en las actividades de la vida diaria. Descriptores: Salud del Anciano; Cognición; Autocuidado; Diabetes Mellitus; Atención Secundaria de Salud. 


\section{INTRODUCTION}

Aging is defined as the accumulation of a variety of molecular and cellular damages that may lead to a gradual loss in the individual's physiological reserves, increasing the risk of disease ${ }^{(1)}$. Old age is one of the major themes of interests to the society due to the epidemiological transition the world is experiencing. Being free from disease or illness is not a requirement for healthy aging, as many elderly people have one or more health problems $\mathrm{s}^{(2)}$. There are morphological, functional, biochemical and psychosocial changes, which determine the progressive loss of the individual's ability to adapt to the environment ${ }^{(3)}$ which, when well controlled, have little influence on their well-being. Everyone can experience healthy aging. The WHO defines Healthy Aging"as the process of developing and maintaining functional capacity that allows for well-being in old age ${ }^{\prime \prime(2)}$. The elderly population is most affected by chronic diseases, especially type 2 diabetes mellitus (DM2). This makes them fragile in the face of certain physical efforts leading to a decline in the development of simple activities that can compromise their quality of life ${ }^{(4-5)}$. The increased incidence and prevalence of Diabetes Mellitus (DM) throughout the world can be explained by the growing urbanization and the adoption of unhealthy living habits ${ }^{(6)}$. The type 2 diabetes is considered a "global epidemic of the 21st century"(7). The disease is associated to higher rates of hospitalizations, greater use of health services, as well as a higher incidence of cardiovascular and cerebrovascular diseases; with that, one can predict the burden it will represent in the coming years for health systems in all countries, regardless of their economic development ${ }^{(8)}$. Diabetes-related complications may be associated with cognitive deficits, including executive function, psychomotor efficiency, intelligence, memory and learning(6). These may also involve memory, orientation and concentration deterioration, in addition to leading to difficulties in perceiving themselves in the social context. This ultimately decreases the functional autonomy, which makes necessary the monitoring of family members depending on the degree of damage and the reduction in physiological, sensory and cognitive capabilities ${ }^{(9)}$. Increasing life expectancy, added to the birth rate reduction and the high projection of chronic degenerative diseases, such as dementia, challenge professionals to develop prevention, promotion and intervention strategies in search for a well-assisted and oriented aging process ${ }^{(10)}$. In order to support the functional capacity of the elderly to meet their basic needs, interact with other people and contribute to society. Functional capacity is composed of the individual's intrinsic capacity, comprising all mental and physical characteristics. The level of intrinsic capacity is influenced by a number of factors, such as the presence of diseases, injuries and age-related changes ${ }^{(2)}$. Given the importance of the subject as a public health problem and due to its significant impact in these people's quality of life, this study aimed at assessing the influence of Diabetes Mellitus in the cognitive and functional capacity of elderly adults.

\section{OBJECTIVE}

To analyze the cognitive capacity and functional development of elderly people with and without type 2 diabetes mellitus.

\section{METHODS}

\section{Ethical aspects}

The research involved human beings and was carried out in accordance with Resolution No. 466/12 of the National Health Council. The project was approved by the Ethics Committee of the Foundation for Education and Research in Health Sciences. All participants were provided with information on the research and signed a free and informed consent term (FICT).

\section{Design, period and place of study}

Case-control study, involving elderly people with and without DM2. This study was conducted in a secondary care public hospital. Two outpatient clinics were the collection sites, namely: geriatrics and endocrinology. The approach to the subjects was through interviewing randomly selected patients in outpatient consultation. The collection period was from March to September 2018. This is an observational case-control study, guided by the STROBE tool.

\section{Sample}

The total sample consisted of 218 patients, divided into two groups: 109 with DM2 and 109 without the disease.

\section{Inclusion and exclusion criteria}

Inclusion criteria were elderly people aged 60 years or more, both genders, who agreed to participate in the research. Elderly with visual and auditory deficiencies, and who did not have $\mathrm{HbA} 1 \mathrm{c}$ (glycated hemoglobin) examinations in the last six months, were excluded which allowed classifying them based on glycemic control, and finally, those who did not sign the FICT.

\section{Study protocol}

The instruments used for cognitive and functional assessment in this research were: Mini Mental State Examination - MMSE, Clock Test - TDR, Verbal Fluency Test - FV with Animal and Fruit category, Katz Index - IK for Basic Activities of Daily Living and Lawton IL Index for Instrumental Activities of Daily Living.

Mini-Mental ${ }^{(11)}$ which addresses issues concerning orientation, memory and attention, totaling up to 21 points, and specific skills such as naming and understanding, with a maximum score of 9 points, amounting to a total score of 30 points. Higher values indicate a better cognitive performance. Passing scores: Illiterate $\leq 15 ; 1$ to 11 years of education $\leq 22$; Schooling greater than 11 years $\leq 27^{(12)}$.

The Verbal Fluency Test ${ }^{(13)}$ evaluates the capacity of memory storage (interpretation and meaning of words), attention, and mastery of language. It stimulates the association between word and object, which in this study involves the part with animals and fruits. The test works with memorization (ability to store information) of the greatest possible number of words in a set time of 1 minute.

The Clock Test ${ }^{(14)}$ has been a widely used tool in the clinical practice to assess the decreased cognitive capacity due to aging. The patient is requested to draw a clock with the hands marking 2:45 pm and all numbers should be represented, as well as 
the clock format. This is a simple and very precise test regarding sensitivity and efficiency for the early diagnosis of dementia.

To evaluate the functional autonomy of the elderly under study, were used: assessment of activities of daily living - Katz Index, developed to measure the physical functioning of people with chronic diseases through a form with three classification categories: independent, partially dependent (assistance for the activity), or fully dependent ${ }^{(15)}$. One observed the functional performance of six activities regarded as basic for the everyday life of the elderly, namely: bathing, dressing, going to the bathroom, moving, being continent, and feeding.

Evaluation of instrumental activities of daily living - Lawton Index ${ }^{(16)}$, instrument which assesses the independence level of the elderly, consisting of eight tasks: using the telephone, going shopping, preparing foods, doing house work, laundry, using transportation means, preparing medication and managing money, by assigning scores according to the ability of the subject to perform these activities ${ }^{(17-18)}$.

\section{Analysis of results and statistics}

The study was divided into descriptive and associativity analyses, and logistic and linear regressions. Data analyses were performed in the program IBM SPSS (Statistical Package for the Social Sciences 21), 2012. The significance level used throughout the study was $5 \%$.
In descriptive analysis, qualitative variables are presented by means of frequency and percentage. Quantitative analysis is presented through the descriptive measures of minimum, maximum, mean, median and standard deviation.

\section{RESULTS}

One can see that, for elderly patients with type 2 Diabetes Mellitus, the mean age was 68.3 years, very similar to the mean age of those without diabetes -69.0 years old. The mean $\mathrm{HbA} 1 \mathrm{c}$ was 7.2 and the mean time since diagnosis was 14.6 years.

All cognitive assessment instruments presented lower mean values for elderly people without diabetes. The mean MMSE was 22.3 points, against 24.8 for people without diabetes.

In the verbal fluency tests, the value attained for the category Animals was on average 11.7 points for people with diabetes and 12.9 points for elderly people without the disease. In the category Fruits, however, the mean results were 10.3 (DM2) and 11.0 (without DM2).

Only in the clock test a significant influence of $\mathrm{HbA} 1 \mathrm{c}$ could be observed, besides the education constant. Lower $\mathrm{HbA} 1 \mathrm{c}$ values influenced the increased scores in this test, as well as higher education levels, explaining the increase in scores on the clock test, whose mean values were 3.9 for the group with DM2 compared to the mean 5.8 for those without diabetes.

Table 1 - Descriptive analysis of quantitative variables elderly people with and without type 2 Diabetes Mellitus, attended from March to September 2018 at the public hospital of secondary health care, Brasilia, Federal District, Brazil, 2018

\begin{tabular}{|c|c|c|c|c|c|c|c|c|}
\hline \multirow[b]{2}{*}{ Variable } & \multicolumn{4}{|c|}{ Elderly people with Diabetes } & \multicolumn{4}{|c|}{ Elderly people without Diabetes } \\
\hline & Minimum & Maximum & Mean & $\begin{array}{l}\text { Standard } \\
\text { deviation }\end{array}$ & Minimum & Maximum & Mean & $\begin{array}{l}\text { Standaro } \\
\text { deviation }\end{array}$ \\
\hline Age & 60.0 & 91.0 & 68.3 & 6.6 & 60.0 & 95.0 & 69.0 & 7.1 \\
\hline $\mathrm{HbA} 1 \mathrm{C}$ & 5.1 & 11.3 & 7.2 & 1.4 & - & - & - & - \\
\hline Time diagnosis (years) & 0.5 & 53.0 & 14.6 & 11.5 & - & - & - & - \\
\hline Mini-Mental & 12.0 & 29.0 & 22.3 & 4.6 & 17.0 & 30.0 & 24.8 & 3.2 \\
\hline Verbal Fluency Animals & 4.0 & 19.0 & 11.7 & 3.8 & 5.0 & 21.0 & 12.9 & 3.4 \\
\hline Verbal Fluency Fruits & 3.0 & 18.0 & 10.3 & 3.2 & 5.0 & 18.0 & 11.0 & 3.0 \\
\hline Clock Test & 1.0 & 9.0 & 3.9 & 2.7 & 1.0 & 10.0 & 5.8 & 2.7 \\
\hline
\end{tabular}

Table 2 - Descriptive analysis of quantitative variables of elderly people with and without type 2 Diabetes Mellitus, attended from March to September 2018 at the public hospital of secondary health care, Brasilia, Federal District, Brazil, 2018

\begin{tabular}{|c|c|c|c|}
\hline \multirow{2}{*}{ Variable } & & \multicolumn{2}{|c|}{ Frequency (\%) } \\
\hline & & Patients with Diabetes & Patients without Diabetes \\
\hline Gender & $\begin{array}{l}\text { Male } \\
\text { Female }\end{array}$ & $\begin{array}{l}35(32.1) \\
74(67.9)\end{array}$ & $\begin{array}{l}26(23.9) \\
83(76.1)\end{array}$ \\
\hline Schooling & $\begin{array}{l}\text { None } \\
\text { Some elementary school } \\
\text { Elementary school } \\
\text { Some high school } \\
\text { High school } \\
\text { Some Higher Education } \\
\text { Complete Higher Education } \\
\text { Graduate }\end{array}$ & $\begin{array}{l}16(14.7) \\
41(37.6) \\
12(11.0) \\
11(10.1) \\
25(22.0) \\
0(0.0) \\
4(3.7) \\
0(0.0)\end{array}$ & $\begin{aligned} 17 & (15.6) \\
31 & (28.4) \\
12 & (11.0) \\
3 & (2.8) \\
32 & (29.4) \\
1 & (0.9) \\
12 & (11.0) \\
1 & (0.9)\end{aligned}$ \\
\hline Basic Activities of Daily Living - Katz Index & $\begin{array}{l}\text { Independence } \\
\text { Care } \\
\text { Dependency }\end{array}$ & $\begin{array}{c}60(55.0) \\
49(45.0) \\
0(0.0)\end{array}$ & $\begin{array}{c}84(77.1) \\
25(22.9) \\
0(0.0)\end{array}$ \\
\hline Instrumental Activities of Daily Living Lawton Index & $\begin{array}{l}\text { Independence } \\
\text { Care } \\
\text { Dependency }\end{array}$ & $\begin{array}{c}48(44.0) \\
53(48.6) \\
8(7.3)\end{array}$ & $\begin{array}{c}74(67.9) \\
33(30.3) \\
2(1.8)\end{array}$ \\
\hline Total & & $190(100.0)$ & $190(100.0)$ \\
\hline
\end{tabular}


In evaluating Basic Activities of Daily Living, 'independence' was predominant in both groups, albeit more pronounced in the group without diabetes. For Instrumental Activities of Daily Living, nonetheless, the dominant category was 'independence' for the group without diabetes and 'assistance' (help) for the DM2 group.

One could note that elderly people with higher education levels have had significantly better performance in tests (MMSE, VFT Animals, VFT Fruits, and Clock Test).
Multiple linear regressions were performed for: MEEM cognitive assessment, VFT Animals, VFT Fruits, and Clock Test. Variables included in the model as explanatory were: age, gender, $\mathrm{HbA} 1 \mathrm{c}$, time since diagnosis, and education.

All regressions were significant, which shows the linear model was well used for these data. The variable best explained by the model with those 5 response variables was the MMSE cognitive assessment, followed by age and education.

Table 3 - Multiple linear regression models for the variables, Brasilia, Federal District, Brazil, 2018

\begin{tabular}{|c|c|c|c|c|c|c|c|c|}
\hline \multirow{2}{*}{\multicolumn{2}{|c|}{ Response variable }} & \multicolumn{2}{|c|}{ Non-standard coefficients } & \multicolumn{2}{|c|}{ Standard coefficients } & \multirow{3}{*}{$\frac{P}{0.000}$} & \multicolumn{2}{|c|}{$95 \% \mathrm{Cl}$ for B } \\
\hline & & \multirow{2}{*}{$\frac{\text { B }}{35.346}$} & \multirow{2}{*}{$\begin{array}{c}\text { Standard error } \\
4.276\end{array}$} & \multirow{2}{*}{ Beta } & \multirow{2}{*}{$\frac{\mathbf{t}}{8.266}$} & & \multirow{2}{*}{$\frac{\text { Inferior Limit }}{26.866}$} & \multirow{2}{*}{$\begin{array}{c}\text { Superior Limit } \\
43.826\end{array}$} \\
\hline Cognitive & (Constant) & & & & & & & \\
\hline Assessment - & Age & -0.215 & 0.055 & -0.307 & -3.914 & 0.000 & -0.324 & -0.106 \\
\hline \multirow{4}{*}{ MEEM } & Gender & -0.877 & 0.725 & -0.089 & -1.211 & 0.229 & -2.314 & 0.560 \\
\hline & Glycated Hemoglobin \% & -0.144 & 0.247 & -0.043 & -0.585 & 0.560 & -0.634 & 0.345 \\
\hline & Time since diagnosis & 0.051 & 0.031 & 0.127 & 1.635 & 0.105 & -0.011 & 0.112 \\
\hline & Schooling & 1.675 & 0.210 & 0.584 & 7.968 & 0.000 & 1.258 & 2.092 \\
\hline Verbal Fluency & (Constant) & 22.336 & 4.323 & & 5.167 & 0.000 & 13.762 & 30.910 \\
\hline \multirow[t]{5}{*}{ Test - animals } & Age & -0.069 & 0.056 & -0.121 & -1.244 & 0.216 & -0.179 & 0,041 \\
\hline & Gender & -1.791 & 0.733 & -0.222 & -2.445 & 0.016 & -3.244 & -0.338 \\
\hline & Glycated Hemoglobin \% & -0.482 & 0.250 & -0.174 & -1.929 & 0.056 & -0.977 & 0.013 \\
\hline & Time since diagnosis & -0.045 & 0.031 & -0.138 & -1.440 & 0.153 & -0.107 & 0.017 \\
\hline & Schooling & 0.587 & 0.213 & 0.250 & 2.764 & 0.007 & 0.166 & 1.009 \\
\hline Verbal Fluency & (Constant) & 15.734 & 3.600 & & 4.370 & 0.000 & 8.593 & 22.874 \\
\hline \multirow[t]{5}{*}{ Test - Fruits } & Age & -0.074 & 0.046 & -0.155 & -1.611 & 0.110 & -0.166 & 0.017 \\
\hline & Gender & 0.065 & 0.610 & 0.010 & 0.106 & 0.915 & -1.145 & 1.275 \\
\hline & Glycated Hemoglobin \% & -0.218 & 0.208 & -0.094 & -1.046 & 0.298 & -0.630 & 0.195 \\
\hline & Time since diagnosis & -0.025 & 0.026 & -0.090 & -0.950 & 0.344 & -0.077 & 0.027 \\
\hline & Schooling & 0.704 & 0.177 & 0.357 & 3.977 & 0.000 & 0.353 & 1.055 \\
\hline \multirow[t]{6}{*}{ Clock Test } & (Constant) & 8.106 & 2.888 & & 2.807 & 0.006 & 2.379 & 13.834 \\
\hline & Age & -0.058 & 0.037 & -0.144 & -1.559 & 0.122 & -0.131 & 0.016 \\
\hline & Gender & 0.703 & 0.489 & 0.124 & 1.437 & 0.154 & -0.267 & 1.674 \\
\hline & Glycated Hemoglobin \% & -0.405 & 0.167 & -0.208 & -2.430 & 0.017 & -0.736 & -0.074 \\
\hline & Time since diagnosis & 0.011 & 0.021 & 0.047 & 0.518 & 0.605 & -0.031 & 0.052 \\
\hline & Schooling & 0.646 & 0.142 & 0.392 & 4.552 & 0.000 & 0.365 & 0.928 \\
\hline
\end{tabular}

Table 4 - Multiple binary logistic regression models for the variables, Brasilia, Federal District, Brazil, 2018

\begin{tabular}{|c|c|c|c|c|c|c|c|c|c|}
\hline \multirow{2}{*}{ Response variable } & & \multirow[b]{2}{*}{ B } & \multirow[b]{2}{*}{ S.E. } & \multirow[b]{2}{*}{ Wald } & \multirow[b]{2}{*}{ df } & \multirow[b]{2}{*}{$P$} & \multirow[b]{2}{*}{$\operatorname{Exp}(B)$} & \multicolumn{2}{|c|}{ 95\% Cl for EXP(B) } \\
\hline & & & & & & & & Inferior & Superior \\
\hline Basic Activities of & Age & 0.078 & 0.036 & 4.552 & 1 & 0.033 & 1.081 & 1.006 & 1.161 \\
\hline \multirow[t]{5}{*}{ Daily Living (BADL) } & Gender & -0.763 & 0.453 & 2.844 & 1 & 0.092 & 0.466 & 0.192 & 1.132 \\
\hline & Glycated Hemoglobin & 0.117 & 0.154 & 0.577 & 1 & 0.448 & 1.124 & 0.831 & 1.520 \\
\hline & Time since diagnosis & 0.009 & 0.020 & 0.189 & 1 & 0.664 & 1.009 & 0.970 & 1.049 \\
\hline & Schooling & -0.156 & 0.133 & 1.373 & 1 & 0.241 & 0.856 & 0.659 & 1.111 \\
\hline & Constant & -4.886 & 2.744 & 3.171 & 1 & 0.075 & 0.008 & & \\
\hline Instrumental & Age & 0.049 & 0.036 & 1.851 & 1 & 0.174 & 1.051 & 0.978 & 1.128 \\
\hline Activities of Daily & Gender & -0.500 & 0.463 & 1.164 & 1 & 0.281 & 0.607 & 0.245 & 1.504 \\
\hline \multirow[t]{4}{*}{ Living (IADL) } & Glycated Hemoglobin & 0.174 & 0.160 & 1.182 & 1 & 0.277 & 1.190 & 0.870 & 1.628 \\
\hline & Time since diagnosis & 0.002 & 0.020 & 0.011 & 1 & 0.917 & 1.002 & 0.963 & 1.043 \\
\hline & Schooling & -0.326 & 0.134 & 5.936 & 1 & 0.015 & 0.722 & 0.555 & 0.938 \\
\hline & Constant & -2.873 & 2.763 & 1.081 & 1 & 0.298 & 0.057 & & \\
\hline
\end{tabular}

Table 5 - Association between the variables Schooling and Glycated Hemoglobin (compensated and uncompensated), Brasilia, Federal District, Brazil, 2018

\begin{tabular}{llccc}
\hline & & \multicolumn{2}{c}{ Glycated Hemoglobin } & \\
& & Compensated & Uncompensated & Total \\
\hline Schooling & None & 9 & 7 & 16 \\
& Some elementary school & 15 & 76 & 41 \\
& Elementary school & 6 & 5 & 12 \\
& Some high school & 20 & 5 & 11 \\
& High school & 1 & 5 & 4 \\
Total & Higher Education & 58 & 3 & 109 \\
\hline
\end{tabular}


Multiple binary logistic regressions were performed. The response variables used in the model were: Basic Activities of Daily Living (BADL) and Instrumental Activities of Daily Living (IADL), resulting in $59.6 \%$ of the BADL cases and $65.1 \%$ of the IADL cases.

\section{DISCUSSION}

It could be analyzed that Diabetes Mellitus directly influences the cognitive and functional capacity of elderly people when compared to the control group. As for gender, there was no statistically significant association between groups, showing there was no trend of a given gender presenting more disease. There was a significant association between DM2 and the Basic Activities of Daily Living - BADL ( $X 2=11.784 ; \mathrm{p}<0.001)$ and Instrumental Activities of Daily Living - IADL $(X 2=13.792 ; p<0.001)$ indexes in table 2 . This indicated the group with DM2 had a higher need of assistance for the performance of their activities of daily living. Such information is in agreement with other study by stating that dementia stages are related to the cognitive impairment concomitant with the impairment of living independently. They influence the ability to perform basic and instrumental activities of daily living and can be assessed with the instruments: Mini Mental State Exam, Clock Drawing Test and Functional Activities Questionnaire ${ }^{(19)}$.

Elderly people with DM2 presented 2.747 95\%( $\mathrm{Cl}=1.529$ - 4.926) chance of being classified as requiring assistance for basic activities of daily living, namely: bathing, dressing, feeding, going to the bathroom, being continent and moving. These results can be compared with those of this study, by mentioning that functional decline begins in more complex tasks, such as bathing, and progresses hierarchically until reaching the level of complete dependency, when the patient needs assistance even for feeding ${ }^{(20)}$. Thus, it has been confirmed that elderly people with diabetes have a significant tendency to having lower scores in basic and instrumental activities. functional capacity is one of the best ways of evaluating the conditions of the elderly, since it translates into a broad concept of health, understood as the existence of physical and mental abilities to maintain autonomy and independence, involving multiple aspects of the life of the elderly, health is related to their functional capacity to decide and execute ADLs with autonomy and independence ${ }^{(21-22)}$.

For people with $\mathrm{DM} 2$, what most significantly influenced the BADLs was the age. Every increase in one year of age, the chance of the person passing from the independence level to requiring assistance increases 1.081 times. However, for IADLs, which demand greater independence from the subjects to do activities such as paying bills, make phone calls, moving outside of the house, shopping, preparing foods, doing house work and using medications, as they are more complex; what one can see is that education was a significant evidence factor $(x 2=12.850 ; p=0.049)$. The variable adherence to treatment is related to blood glucose levels in the target range. Elderly people with good glycemic control had proportionally higher levels of education than elderly people without control of the disease. As shown in table 5. (Here she comments that it seems that education $x$ adherence to treatment has not been studied) Education can be seen as a factor that interferes with adherence to treatment. This result was demonstrated in this study, where each increase in the level of education (for example, from some high school to complete high school) represents an increase of $1,385(10,722)$ times in the chances of moving from the assistance / dependent level to independence. There is an acute projection of elderly patients with DM2 among those with low education. Low education can be linked to lack of care and management to prevent the possible development and worsening of the clinical picture of this metabolic disease. The elderly people have intellectual stimulation activities, the longer it takes to lose their connections. In addition, the development of cognitive activities and formal education, which can influence the better performance in cognitive tests, make the brain more adapted to the effects of the disease ${ }^{(22-23)}$. There was a statistical difference in relation to the $\mathrm{HbA} 1 \mathrm{c}$ groups in the target range and in relation to the group without diabetes for the MMSE cognitive assessment tests $(U=3757.0 ; P=0.044)$ and the clock test $(U=3956.0 ; P=0.007)$. Elderly people without diabetes had significantly higher scores on both tests compared to patients with compensated diabetes, and elderly people with decompensated glycated hemoglobin had lower test scores and, statistically, tend to have lower educational levels than elderly people with glycated hemoglobin in the target range. $(X 2=13,230 ; P=0.021)$.

There was also a statistically significant association regarding the variable Schooling in relation to basic $(X 2=14.965$ and $P=$ $0.027)$ and instrumental ( $x 2=31.314$ and $p=0.044)$ activities of daily living. The group classified as "independence" for these activities of daily living presented higher level of education and, consequently, better performances in tests (MMSE, VFT Animals, VFT Fruits, and Clock Test) that the group classified as "assistance and dependence". This is due to the fact that cognitive reserve functions as a compensatory mechanism for elderly people with higher levels of schooling, protecting them from a more severe cognitive decline ${ }^{(24)}$.Education influences the processing speed, attention, executive functions, memory and intelligence ${ }^{(25)}$.

For the variable Schooling, yet, there was association with all quantitative variables analyzed: age $(\mathrm{W}=14.757 ; \mathrm{p}=0.039)$, MMSE cognitive assessment ( $W=92.958 ; p<0.001)$, verbal fluency test - Animals $(W=31.401 ; p=0.011)$, verbal fluency test - Fruits $(\mathrm{W}=34.624 ; \mathrm{p}<0.001)$, and Clock Test $(\mathrm{W}=72.286 ; \mathrm{p}<0.001)$. Regarding the variable Diabetes Mellitus, there was a statistically significant difference for the variables MMSE cognitive assessment $(U=7823.5 ; P<0.001)$, verbal fluency test - Animals $(U=7122.5$ $P=0.011)$, and Clock Test $(U=8226.5 ; P<0.001)$.

Aimed at only studying elderly people with DM2 $(n=109)$, their association with social features and questionnaire scores was evaluated concerning the fact the diabetes was uncompensated $(\mathrm{HbA} 1 \mathrm{c} \geq 7.00)$ or in target range $(\mathrm{HbA} 1 \mathrm{c}<7.00)$. This difference was observed in relation to Schooling, Table 5. People with uncompensated $\mathrm{HbA} 1 \mathrm{c}$ tended to have lower education level than elderly people within target range $\mathrm{HbA} 1 \mathrm{c}(\mathrm{X} 2=13.230 ; \mathrm{p}=0.021)$. This may be related to diabetes education, as this is an essential part of treatment and is associated with better glycemic control. A higher level of knowledge on the disease and its complications is related to an improved quality of life ${ }^{(26)}$. When uncontrolled, it may lead to a crippling process that makes them require constant monitoring since the quality of life is compromised ${ }^{(27)}$. The treatment involves lifestyle changes, in a process of continuous care that usually does not lead to a cure but to disease control ${ }^{(28)}$. 
This difference was also analyzed concerning the other tests (MMSE, VFT Animals, VFT Fruits, and Clock Test) - people with DM2 and uncompensated $\mathrm{HbA} 1 \mathrm{c}$ obtained worse scores in comparison to in target range patients. There was a statistical difference regarding $\mathrm{HbA} 1 \mathrm{c}$ groups (in target range or uncompensated) for all tests; those with uncompensated $\mathrm{HbA1c}$ featured worse scores than in target range elderly people. For the MMSE cognitive assessment $(U=1125.5 ; P=0.031)$, Verbal Fluency Test - Animals $(U=1032.0 ; P=0.006)$, Verbal Fluency Test - Fruits $(U=1130.5$; $\mathrm{P}=0.033)$ and Clock Test $(\mathrm{U}=1032.0 ; \mathrm{P}=0.006)$.

\section{Study limitation}

The interview was conducted on an individual basis; however, the patients were accompanied by family members, interfering in the interview and requiring that questions were repeatedly posed. Nevertheless, we believe we could control such a bias. Another limitation is related to study design, as this is a crosssectional study, which features the assessment at a given time and place. The scarcity of studies aimed at this population and content might have limited the research discussion, but this was the first study performed in this population.

\section{Contributions to the field subheadings}

To increase the scientific knowledge for the nursing area, and to contribute to the literature on elderly health and in the area of adult health.

\section{CONCLUSION}

Elderly people with type 2 diabetes mellitus, statistically, had more activities classified as requiring "assistance" and dependence on basic and instrumental activities of daily living compared to elderly people without the disease. There was a significant difference between the levels of $\mathrm{HbA} 1 \mathrm{c}$ and schooling: $\mathrm{HbA} 1 \mathrm{c}$ values in the target range influenced the increase in scores on cognitive assessment instruments, especially in mini-mental tests and clock design, due to their efficiency in detecting early dementia. In addition, it showed the influence of education as a factor for cognitive and functional performance in elderly people with higher education levels.

With that, this study made possible evaluating that the high glycemic values becomes an autonomy loss factor for these elderly people, compromising cognition and functional performance on activities of daily living. It has also been shown that schooling directly influences disease control. People with higher education levels tend to have better adherence to the treatment of DM2, having behaviors that are easier to be modified, due to health education influences.

Given this, it is necessary to promote continuous health opportunities, with individual involvement and participation of these elderly people to maintain autonomy and independence during the aging process.

In developing a public-health response to ageing, it is thus important not just to consider approaches that ameliorate the losses associated with older age but also those that may reinforce recovery, adaptation and psychosocial growth. These strengths may be particularly important in helping people navigate the systems and marshal the resources that will enable them to deal with the health issues that often arise in older age ${ }^{(29)}$.

\section{FUNDING}

This research was not funding. This research did not receive any specific concession from development agencies in the public, commercial or non-profit sectors.

\section{REFERENCES}

1. Organização Mundial da Saúde (OMS). Relatório mundial de envelhecimento e saúde [Internet]. 2015 [cited 2019 Apr 3]. Available from: https://apps.who.int/iris/bitstream/handle/10665/186468/WHO_FWC_ALC_15.01_por.pdf\%3Bjse

2. World Health Organization (WHO). Ageing and health: factsheet 404[Internet]. 2015 [cited 2019 Jun 9]. Available from: https://www.who. int/news-room/fact-sheets/detail/ageing-and-health

3. Dziechciaz M, Filip R. Biological psychological and social determinants of old age: bio-psycho-social aspects of human aging. Ann Agric Environm Med. 2014;21(4):835-58. https://doi.org/10.5604/12321966.1129943

4. American Diabetes Association. Standards of medical care in diabetes. Diabetes Care. 2017;40(1);5-17. https://doi.org/10.2337/cd16-006

5. Campolina AG, Dini PS, Ciconelli RM. Impacto da doença crônica na qualidade de vida de idosos da comunidade em São Paulo (SP, Brasil). Ciênc Saúde Colet. 2011;16(6):2919-25. https://doi.org/10.1590/S1413-81232011000600029

6. Lopes RMF, Nascimento RFL, Wendt GW, Argimon IL. A diabetes mellitus causa deterioro cognitivo em idosos? Um estudo de revisão. Av Psicol Latino-Am [Internet]. 2013 [cited 2019 Jun 18];31(1):131-9. Available from: http://repository.urosario.edu.co/handle/10336/15754

7. Ferreira SRG, Pititto BA. Aspectos epidemiológicos do diabetes mellitus e seu impacto no indivíduo e na sociedade. In:Tambascia M, Minicucci W, Netto AP. Diabetes na prática clínica: módulo 1. Rio De Janeiro: Sociedade Brasileira Do Diabetes[Internet]. 2014 [cited 2019 Jun 18]. Available from: https://ebook.diabetes.org.br/component/k2/ item/73-capitulo-1-aspectos-epidemiologicos-do-diabetes-mellitus-e-seu-impacto-no-individuo-e-na-sociedade

8. Sociedade Brasileira De Diabetes (SBD). Diretrizes da Sociedade Brasileira de Diabetes: 2017-2018[Internet]. São Paulo: Editora Clannad. 2017 [cited 2019 Apr 9]. Available from: https://www.diabetes.org.br/profissionais/images/2017/diretrizes/diretrizes-sbd-2017-2018.pdf

9. Araujo CCR, Silveira C, Simas JP, Zappelini A, Parcias SR, Guimarães ACA. Aspectos cognitivos e nível de atividade física de idosos. Saúde. 2015;41(2):193-202. https://doi.org/10.5902/2236583415705 
10. Guedes DV, Barbosa AJG, Magalhães NC. Qualidade de vida de idosos com declínio cognitivo: auto e heterorrelatos. Aval Psicol[Internet]. 2013 [cited 2019 Mar 5];12(1):9-17. Available from: http://pepsic.bvsalud.org/scielo.php?script=sci_arttext\&pid=S1677-04712013000100003\&lng=pt

11. Folstein MF, Folstein SE, Mchugh PR. Mini-mental state: a practical method for grading the cognitive state of patients for the clinician. J Psychiatric Res. 1975;12:189-98. https://doi.org/10.1016/0022-3956(75)90026-6

12. Morgado J, Rocha CS, Maruta C, Guerreiro M, Martins IP. Novos valores normativos do mini-mental state examination. Sinapse: Soc Port Neurol [Internet]. 2009 [cited 2018 Nov 15];9(2):164. Available from: https://www.scienceopen.com/document?vid=a248fe22-ccef-41aa-b1d6-b2231fff8239

13. Abwender DA, Swan JG, Bowerman JT, Connolly SW. Qualitative Analysis of verbal fluency output: review and comparison of several scoring methods. Assessment. 2001;8:323-38. https://doi.org/10.1177/107319110100800308

14. Sunderland T, Hill JL, Mellow AM, Lawlor BA, Gundersheimer J, Newhouse PA, et al. Clock drawing in Alzheimer's disease: a novel measure of dementia severity. J Am Geriatric Soc. 1989;37(8):725-9. https://doi.org/10.1111/j.1532-5415.1989.tb02233.x

15. Katz S, Ford AB, Moskowitz RW, Jackson BA, Jaffe MW. Studies of illness in the aged: the index of ADL - a standardized measure of biological and psychosocial function. Jama. 1963;185:914-9. https://doi.org/10.1001/jama.1963.03060120024016

16. Lawton MP, Brody EM. Assessment of elder people: self-maintaining and instrumental activities of daily living. Gerontol. 1969;9:179-86. https://doi.org/https://doi.org/10.1093/geront/9.3_Part_1.179

17. Araújo F, Pais-Ribeiro J, Oliveira A, Pinto C, Martins T. Validação da escala de Lawton e Brody numa amostra de idosos não institucionalizados. In: Leal I, Pais-Ribeiro J, Silva I, Marques S. Actas do $70^{\circ}$ Congresso Nacional de Psicologia da Saúde, Porto [Internet]. 2008 [cited 2019 Mar 8];217-20. Available from: https://www.researchgate.net/ publication/262198389_Validacao_da_Escala_de_Lawton_e_Brody_numa_amostra_de_idosos_nao_institucionalizados

18. Sequeira C. Cuidar de idosos dependentes. Coimbra: Quarteto Editora [Internet]. 2007 [cited 2019 Apr 17]. Available from: https:// repositorio.ucp.pt/bitstream/10400.14/20778/1/Tese\%20Mestrado\%20Pereira.pdf

19. Dantas EHM, Santos CAS. Aspectos biopsicossociais do envelhecimento e a prevenção de quedas na terceira idade[Internet]. Joaçaba: Editora Unoesc. 2017. [cited 2019 Apr 17]. Available from: https://ufsj.edu.br/portal2-repositorio/File/ppgpsi/ebooks/Aspectos_ Biopsicossociais_do_envelhecimento.pdf

20. Cardoso JH, Costa JSD. Características epidemiológicas, capacidade funcional e fatores associados em idoso de um plano de saúde. Ciênc Saúde Colet. 2010;15(6):2871-8. https://doi.org/10.1590/S1413-81232010000600024

21. Rigo II, Paskulin LMG, Morais EP. Capacidade funcional de idosos de uma comunidade rural do Rio Grande do Sul. Rev Gaúcha Enferm. 2010;31(2):254-61. https://doi.org/10.1590/S1983-14472010000200008

22. Moraes EN. Atenção à saúde do idoso: aspectos conceituais[Internet]. Brasília: Organização Panamericana da Saúde. 2012 [cited 2019 Jun 6]. Available from: https://pesquisa.bvsalud.org/portal/resource/pt/lil-713328

23. Cortez DN, Reis IA, Souza DAS, Macedo MML, Torres HC. Complicações e o tempo de diagnóstico do diabetes mellitus na atenção primária. Acta Paulista Enferm. 2015;28(3):250-55. https://doi.org/10.1590/1982-0194201500042

24. Fonseca S, Amante MJ, Araújo L, Morgado M, Nunes T. O Impacto de um programa de estimulação cognitiva em pessoas idosas a residir na comunidade vs institucionalizadas. Acta Gerontol [Internet]. 2016 [cited 2019 Jun 9];2(1):1-9. Available from: http://hdl.handle.net/10400.19/3435

25. Amieva H, Mokri H, Le Goff M, Meillon C, Jacqmin-Gadda H, Foubert-Samier A, et al. Mecanismos compensatórios em indivíduos com maior escolaridade com doença de Alzheimer: um estudo de 20 anos de declínio cognitivo. 2014;137:1167-75. https://doi.org/10.1093/brain/awu035

26. Nascimento RAS, Batista RTS, Rocha SV, Vasconcelos LRC. Prevalência e fatores associados ao declínio cognitivo em idosos com baixa condição econômica: estudo monidi. J Bras Psiquiatr. 2015;64(3):187-92. https://doi.org/10.1590/0047-2085000000077

27. Assunção TS, Ursine PGS. Estudo de fatores associados à adesão ao tratamento não farmacológico em portadores de diabetes mellitus assistidos pelo Programa Saúde da Família, Ventosa, Belo Horizonte. Ciênc Saúde Colet. 2008. https://doi.org/10.1590/S1413-81232008000900024

28. Menes CFM, Santos ALS. O cuidado na doença de Alzheimer: as representações sociais dos cuidadores familiares. Saúde Soc. 2016;25(1):121-32. https://doi.org/10.1590/S0104-12902015142591

29. Huber M, Knottnerus JA, Green L, Van der Horst H, Jadad AR, Kromhout D. How should we define health? BMJ. 2011;343:4163. https://doi. org/10.1136/bmj.d4163 